\title{
Perempuan dan Pelacuran dalam Kumpulan Cerpen Genduk Dukuh Seti Karangan Rohana Handaningrum Sebuah Kajian Feminis Radikal
}

\author{
Laura Andri Retno M \\ Fakultas Ilmu Budaya, Universitas Diponegoro \\ lauraandrirm@yahoo.co.id
}

\begin{abstract}
Prostitution or prostitution is a phenomenon in people's lives and is considered a "social problem". The general view states that the emergence of prostitution is based on a sense of women's helplessness in aspects of life when compared to men. This perception is not only found in social reality. The condition of women as objects also appears in literary works, as a reflection of people's perceptions. Therefore, it takes a study in the perspective of feminism, especially radical feminists to explore the issue of prostitution that occurs in women. The feminist literary criticism approach was carried out in this study with the type of qualitative research. Data was taken from the collection of Genduk Dukuh Seti short stories written by Rohana Handaningrum. The study was conducted aimed at describing the elements of radical feminism found in texts. The results of this study indicate that there are elements of radical feminism in the cepen group. The power relations of men and women are shown in the doctrine of marriage and the traditional ties that bound women. Whereas the removal of virginity and prostitution is a form of women's power over their bodies.
\end{abstract}

Keywords: radical feminism, women, collection of short stories.

\section{Intisari}

Prostitusi atau pelacuran merupakan fenomena dalam kehidupan masyarakat dan dianggap sebagai"masalah sosial". Pandangan umum menyatakan bahwa munculnya prostitusi didasari oleh rasa ketidakberdayaan perempuan dalam aspek kehidupan apabila dibandingkan dengan laki-laki. Persepsi tersebut tidak hanya terdapat pada realitas sosial. Kondisi perempuan sebagai objek juga muncul dalam karya sastra, sebagai cerminan dari persepsi masyarakatnya. Oleh karena itu, diperlukan kajian dalam perspektif feminisme khususnya feminis radikal untuk mengupas persoalan prostitusi yang terjadi pada perempuan. Pendekatan kritik sastra feminis digunakan dalam penelitian ini dengan jenis penelitian bersifat kualitatif. Data diambil dari kumpulan cerpen Genduk Dukuh Seti karangan Rohana Handaningrum. Penelitian dilakukan bertujuan untuk mendeskripsikan unsur feminisme radikal yang terdapat dalam teks-teks. Hasil penelitian ini menunjukkan bahwa terdapat unsur feminisme radikal dalam kumpulan cepen tersebut. Relasi kuasa laki-laki dan perempuan ditunjukkan dalam doktrin perkawinan dan ikatan tradisi yang membelenggu perempuan. Sedangkan penghilangan keperawanan dan pelacuran merupakan bentuk kuasa perempuan terhadap tubuhnya.

Kata Kunci: feminisme radikal, perempuan, kumpulan cerpen. 


\section{Pendahuluan}

Persoalan perempuan yang berkaitan dengan penindasan, kekerasan, bias gender, eksistensi, dan perjuangan merupakan tema yang banyak dibicarakan dalam kehidupan masyarakat. Patriarki dengan ideologinya selalu disebut sebagai penyebab utama munculnya ketidakadilan gender yang mengakibatkan penindasan dan kekerasan yang dialami perempuan.

Nilai-nilai dalam ideologi patriarki membentuk pola pikir dan perilaku masyarakatnya. Nilai-nilai tersebut memposisikan perempuan sebagai objek bukan subjek dalam kehidupan mereka. Budaya patriarki menempatkan posisi sosial laki-laki lebih tinggi daripada perempuan sehingga masyarakat cenderung menganggap wajar adanya perilaku pelecehen terhadap perempuan dalam peristiwa sekecil apapun. Hal ini berkaitan dengan adanya relasi timpang antara yang mendominasi (kaum maskulin/superior) dengan yang didominasi (kaum feminine /inferior). Dalam kondisi tersebut perempuan tersubordinasi, sehingga memiliki fungsi, peran, dan kedudukan yang stereotip relatif rendah.

Persoalan perempuan menjadi hal yang banyak dibicarakan dalam karya sastra Indonesia. Persoalan gender khususnya yang berhubungan dengan sosok, eksistensi dan relasi perempuan dalam hubungannya dengan laki-laki sering kali menjadi fokus cerita. Novel berisi kumpulan cepen berjudul Genduk Dukuh Seti karangan Rohana Handaningrum yang terbit tahun 2014 merupakan representasi karya sastra dari realitas dunia nyata. Proses kelahiran karya sastra tersebut diprakondisikan oleh kode sosial budaya yang melingkupi pengarang. Karya sastra merupakan karya budaya dan karenanya ia merupakan teks budaya suatu masyarakat. Kumpulan cerpen Genduk Dukuh Seti merupakan ungkapan wacana kebebasan dan pembebasan perempuan yang ingin disampaikan pengarang pada pembacanya. Rohana mampu mengilustrasikan tokoh utama sebagai perempuan yang ulet, tidak mengenal kata menyerah dalam berusaha dan mau bekerja keras demi kehidupannya. Perempuan yang direfleksikan dalam novel ini bukan perempuan yang cengeng dan hanyut dengan kesedihannya serta terpuruk di dalam penderitaan. Pengalaman pahitnya menjalani kehidupan menjadi pendorong untuk tetap menegakkan kepala. 
Agar tokoh perempuan dalam novel yang keberadaannya selalu tidak netral dari ideologi pengarangnya ini bisa digali dengan semestinya dan tuntas maka diperlukan analisis yang tidak bias gender. Dengan kata lain, analisis permasalahan perempuan harus dilakukan melalui perspektif perempuan. Inilah yang disebut Hellwig "membaca sebagai seorang perempuan" (Hellwig, 2003: 10) dalam menganalisis permasalahan perempuan yang dikemukakan dalam teks atau novel. Dengan begitu, melalui penelitian ini diharapkan nantinya dapat ditemukan gambaran nilai perjuangan perempuan melawan ketidakadilan yang diciptakan masyarakat dan budayanya sendiri.

Salah satu aliran dalam pemikiran feminis adalah feminis radikal. Asumsi dasar pemikirannya, mereka menganggap penindasan terhadap perempuan oleh lakilaki berakar pada jenis kelamin laki-laki itu sendiri beserta ideologi patriarkinya. Dengan demikian kaum lelaki secara biologis maupun politis adalah bagian dari permasalahan. Aliran ini menganggap bahwa penguasaan fisik perempuan oleh lakilaki, seperti hubungan seksual adalah bentuk dasar penindasan terhadap kaum perempuan (Jaggar dalam Fakih,2001:84-85).

Feminisme radikal mempermasalahkan tubuh serta hak-hak reproduksi, seksualitas (termasuk lesbianisme), seksisme, relasi kuasa perempuan dan laki-laki, dan dikotomi privat-publik. The personal is political menjadi gagasan yang mampu menjangkau permasalahan perempuan sampai ranah privat, masalah yang dianggap paling tabu untuk diangkat ke publik. Informasi atau pandangan buruk (black propaganda) banyak ditujukan kepada feminis radikal.

Sejalan dengan proyek feminis yang bertujuan mengakhiri dominasi pria, kritik sastra feminis mengambil peran sebagai suatu bentuk kritik negosiasi, bukan sebagai bentuk konfrontasi. Kritik ini dilakukan dengan tujuan untuk menumbangkan wacanawacana dominan, bukan untuk berkompromi dengan wacana dominan tersebut. Kritik sastra feminis lebih dari sekedar perspektif. Ia menampilkan kecanggihan dengan menggunakan aliansi strategi dengan teori-teori kritis (Ruthven, 1990:32).

Kumpulan cerpen Genduk Dukuh Seti merupakan penggambaran perempuan Dukuhseti yang memiliki kemantapan menjadi seorang sindir atau ledek dan masuk dalam dunia prostitusi. Kemantapan menjadi seorang pelacur merupakan upaya untuk memaknai eksistensi diri sebagai perempuan sekaligus menunjukkan bahwa menjadi pelacur berarti menguasai dan menundukkan laki-laki, bukan dikuasai dan ditundukkan 
laki-laki seperti halnya dalam sebuah lembaga pernikahan. Melalui analisis feminis radikal dapat diketahui bentuk perlawanan tokoh utama dari rasa ketertindasan yang dialaminya.

\section{Metode Penelitian}

Penelitian ini bersifat deskriptif kualitatif dengan menggunakan jenis penelitian pustaka (library research). Penelitian ini fokus pada pendeskripsian fakta-fakta mengenai feminisme radikal ditinjau dari aspek ketidakadilan gender dalam kumpulan cerpen Genduk Dukuh Seti karangan Rohana Handaningrum. Adapun langkah-langkah dalam penelitian ini adalah sebagai berikut: 1) mencari data dengan cara membaca dan memahami novel; 2) mengklasifikasikan data; 3) menganalisis data dengan menggunakan pendekatan feminis; 4) menarik kesimpulan dari analisis tersebut.

\section{Pembahasan}

Seperti yang dikemukakan dalam bagian pendahuluan, penelitian ini fokus pada satu teori feminisme, yaitu feminisme radikal. Berdasarkan hal tersebut, maka penelitian yang dilakukan terpusat pada bentuk perlawanan yang dilakukan tokoh perempuan dalam kumpulan cerpen Genduk Dukuh Seti karya Rohana Handaningrum.

\section{Relasi Kuasa Laki-laki dan Perempuan}

Munculnya ketertindasan yang dialami oleh perempuan disebabkan karena posisinya sebagai second sexes dalam sistem kelas jenis kelamin. Menurut pandangan feminis radikal, faktor biologis merupakan dasar pembeda gender. Penguasaan fisik perempuan oleh laki-laki merupakan bentuk penindasan terhadap perempuan. Lakilaki bersikap sewenang-wenang karena merasa memiliki kuasa atas tubuh dan hidup perempuan.

- Doktrin Perkawinan

Pandangan patriarki menilai bahwa perkawinan adalah satu-satunya cara perempuan untuk mendapatkan dukungan dan pembuktian diri terhadap eksistensinya. Perkawinan merupakan takdir yang harus diterima perempuan. Hal ini dikarenakan fungsi perempuan adalah memenuhi kebutuhan seks laki-laki (suami) sekaligus 
Laura Andri Retno M, Perempuan dan Pelacuran dalam Kumpulan Cerpen Genduk Dukuh Seti Karangan Rohana Handaningrum Sebuah Kajian Feminis Radikal

mengurusi segala kebutuhan suami serta memberikan keturunan dalam masyarakat. Oleh karena itu, gagasan kepemilikan suami atas istri telah memberikan kekuasaan kepada laki-laki untuk mendapatkan segala bentuk pengabdian, kebaktian, dan pelayanan dari perempuan.

Dalam kumpulan cerpen Genduk Dukuh Seti, tokoh simbok digambarkan sebagai perempuan asli Dukuh Seti keturunan Portugis yang memiliki kesempurnaan secara fisik. Sebagai seorang sindir/ledek, simbok mengalami keterpurukan setelah diperkosa beramai-ramai oleh para berandalan dalam peristiwa kegaduhan yang terjadi di Dukuh Seti. Kekerasan fisik dan psikis mengakibatkan kehancuran dalam diri tokoh. Laki-laki ditampilkan sebagai penyelamat dalam kondisi chaos ini. Perempuan dapat keluar dari masalah yang dihadapi hanya setelah ia terikat perkawinan dengan laki-laki.

"itu...ya karena bapakmu orang baik, Mi. Bapakmu yang menyelamatkan simbokmu." ( $G D S, 2014: 106)$

Simbok bilang setiap malam Mbah Gandring datang memberikan air doa untuk ketenangan jiwa simbok. Sampai di hari ke-40, Mbah Gandring datang menyatakan pada simbok, jika simbok ingin selamat dalam kehidupannya, ia harus menikah dan berhenti menjadi sindir. (GDS, 2014:118)

Inferioritas perempuan (istri) kepada laki-laki (suami) terlihat kuat dalam novel tersebut. Sifat kepatuhan, kesetiaan, kepasrahan, dan kepatuhan kepada suami adalah tugas dan kewajiban seorang istri. Meskipun tokoh simbok adalah bekas sindir terkenal di Kabupaten Pati dan cukup berperan dalam menyokong perekonomian desanya namun usaha itu tidak diperhitungkan sebagai bentuk perjuangan perempuan untuk bereksistensi. Justru pelecehan seksual, kekerasan fisik, psikis dan verbal kerap diterimanya. Penilaian masyarakat menjadi berbeda ketika simbok mengubah peran tidak lagi menjadi sindir tapi bersedia menikah dan menjadi istri yang mengorbankan diri untuk kesenangan atau kepentingan suaminya. Meskipun pada akhirnya dalam perkawinan terjadi hubungan yang timpang karena kekuasaan suami menjadi lebih dominan. Sikap menerima takdir atau fatalistik dalam menerima nasib hidup, dalam pandangan novel ini, merupakan bagian dari rencana Tuhan.

- Ikatan Nilai tradisi 
Standart kecantikan atau berterimanya fisik perempuan dalam tatanan patriarki, tidak dapat dipisahkan dengan bagaimana posisi perempuan dalam tatanan masyarakat. Masyakarat menciptakan aturan untuk mengikat perempuan. Biasanya aturan tesebut tidak bersifat netral atau menguntungkan tetapi lebih pada bentuk ikatan yang merugikan.

Perempuan harus rajin minum jamu, berdandan, berlulur,dll. Dalam berbusanapun perempuan tidak bisa sembarangan jka ingin mendapatkan lakilaki yang bibit, bebet dan bobotnya pilihan. (GDS, 2014: 97)

Bagi orang Jawa pada umumnya, tentu pamali bagi anak gadis berlari dan mengangkat jarit tinggi-tinggi, selain karena betisnya tesingkap, kata orang Cuma perempuan pembangkangdan tidak bisa diatur yang melakukan itu. Itulah kenapa jarit menjadi pakaian kehormatan perempuan jawa, simbol kelemahlebutan, simbol ketaatan, juga simbol kehati-hatian. Jarit berfungsi sebagai "pengontrol" langkah perempuan Jawa, supaya tidka "kebat kliwat", tidak mendahului langkah laki-laki. (GDS, 2014:98)

Hegemoni nilai-nilai Jawa pada kutipan di atas menunjukkan bahwa perempuan harus memiliki citra yang feminin. Perempuan di kontrol oleh aturanaturan dalam setiap tingkah lakunya. Jika mereka bertingkah sebaliknya, maka ada konsekuensi yang harus diterima, diantaranya adalah mendapat komentar "saru", tidak pantas dan dianggap memalukan. Dalam hal ini perempuan berada pada posisi yang tidak menguntungkan. Mereka dituntut untuk setia, berbakti, sempurna dalam tampilan fisik sedangkan laki-laki tidak dituntut apa-apa.

\section{Perempuan, Seks dan Tubuh}

Feminis radikal menganggap penindasan terhadap perempuan oleh laki-laki berakar pada jenis kelamin laki-laki beserta ideologi patriarkinya. Dengan demikian, laki-laki secara biologis maupun politis adalah bagian dari permasalahan. Feminis radikal mempersoalkan hal-hal yang selama ini dianggap tabu untuk dibicarakan masyarakat. Persoalan tersebut meliputi kekerasan seksual, kebebasan menentukan kepuasan diri bagi perempuan, serta berbagai kasus pelecehan seksual yang dialami perempuan.

- Keinginan Melepas Keperawanan 
Laura Andri Retno M, Perempuan dan Pelacuran dalam Kumpulan Cerpen Genduk Dukuh Seti Karangan Rohana Handaningrum Sebuah Kajian Feminis Radikal

Tokoh simbok melepas keperawanannya tanpa didahului pernikahan. Sebagai seorang sindir, ia memilih melepaskan keperawanannya dengan laki-laki tanpa sebuah ikatan. Menurutnya, dengan melepas keperawanan, perempuan mendapatkan tempat yang sama dengan laki-laki terhadap kekuasaan atas kelaminnya. Dalam kumpulan cerpen tersebut, tokoh simbok menjelaskan mengenai seksualitas antara laki-laki dan perempuan melalui pemikirannya. Ia memilih tidak peduli dengan dosa karena hubungan seksual yang dilakukan oleh laki-laki dan perempuan selalu berada di alam bawah sadar. Relasi kekuasaan hadir ketika hubungan seksual manusia berada dalam kondisi alam bawah sadar. Relasi ini menjadikan manusia melihat yang lain sebagai objek. Manusia tidak berhubungan dengan pasangan sebagai subjek dengan subjek, sehingga mereka tidak pernah setara.

Selain itu, oleh budaya patriarki keperawanan perempuan dianggap sebagai satusatunya harta yang paling berharga. Ide mengenai keperawanan ini tentu saja tidak jauh dari ide mengenai religiusitas perempuan. Karena perempuan dianggap religius akan menjaga keperawananannya dan diberikan pada laki-laki yang berhak memilikinya. Dalam konsep feminis radikal, perempuan yang demikian dianggap tidak memiliki hasrat karena ia terikat pada aturan yang melegitimasinya.

Tokoh simbok melalui sikapnya mencoba melawan patriarki dan menegaskan bahwa perempuan berhak mengatur kelaminnya sendiri tanpa harus dipengaruhi oleh lingkungan sosial yang ada. Ia merebut kembali kendali atas seksualitas perempuan dengan menuntut hak untuk mempraktikkan apapun yang dapat memberikan kenikmatan dan kepuasan. Hubungan seksual yang ideal adalah partner setara yang sama-sama memberikan persetujuan, dan yang benegoisasi untuk memaksimalkan kenikmatan dan kepuasan seksual satu sama lain, dengan cara apapun yang dipilihnya (Tong, 1998: 94).

- Seks, Tubuh dan Pelacuran

Dalam kumpulan cerpen Genduk Dukuhseti, tokoh perempuan berhak melakukan apa yang dia hendaki dengan tubuhnya. Dengan slogan "yang pribadi adalah politis", menunjukkan bahwa penindasan dalam lingkup privat merupakan penindasan dalam lingkup publik. Pernyataan ini memiliki makna "perempuan adalah pemilik tubuh mereka sendiri”. Seksual dan pelacuran adalah cara yang digunakan 
Laura Andri Retno M, Perempuan dan Pelacuran dalam Kumpulan Cerpen Genduk Dukuh Seti Karangan Rohana Handaningrum Sebuah Kajian Feminis Radikal

perempuan untuk merepresentasikan tubuh.

Seksualitas perempuan telah diatur dalam tatanan masyarakat patriarkis. Seksualitas yang diatur dalam tatanan masyarakat termasuk didalamnya adalah seksualitas feminin yang menginginkan serta bergantung pada seksualitas maskulin. Meskipun demikian, bentuk seksual yang berbeda dari masing-masing individu memungkinkan kebebasan bagi perempuan untuk memilih seksualnya, dengan siapa ia berhasrat dan bagaimana ia menyalurkan hasratnya.

Tokoh simbok yang berprofesi sebagai sindir tidak tidak dapat dipisahkan dengan kegiatan pelacuran. Sehingga tubuh dan seksualitasnya menjadi suatu arena pertarungan berbagai kepentingan dan perubahan. Seksualitas dan pelacuran merupakan suatu arena kontestasi berbagai kepentingan biologis, psikologis, ekonomi, kultural, hingga politik. Aktivitas seksual yang bersifat privat menjadi bagian dari fungsi sosial ketika ia berkaitan dengan kelangsungan hidup dirinya dan orang-orang sekitarnya. Dalam prosesnya, ketika seksualitas ditujukan entah sebagai sarana prokreasi, untuk aspek ekonomi, kepuasan hasrat, kepuasan psikologis, hingga “tuntutan masyarakat", seksualitas membutuhkan orang lain sebagai perantara.

Dalam pandangan feminis radikal, pelacuran dan erotisme atau hasrat perempuan merupakan hal yang natural, yang harus disadari oleh semua perempuan. Erotisme adalah sumber energi perempuan terdalam yang berakar dari kekuatan perempuan, kekuatan perempuan untuk mengerti dirinya sendiri. Erotisme tidak hanya menyangkut hal yang bersifat seksual tapi lebih pada perasaaan dan pengetahuan perempuan. Selama ini patriarki menjauhkan perempuan dari erotisme dan membuat stigma bahwa erotisme merupakan pornografi. Padahal dua hal tersebut tidaklah sama karena pronografi lebih pada sensasi tanpa perasaan.

Ungkapan "aku tidak ingin menikah dan tidak terlalu suka membicarakan lakilaki" (GDS, 2014: 97) berkaitan dengan pendapat feminis radikal menolak perkawinan bukan hanya dalam teori, melainkan sering pula dalam praktek. Kumpulan cerpen Genduk Dukuh Seti merupakan penggambaran perempuan Dukuhseti yang memiliki kemantapan menjadi seorang sindir atau ledek dan masuk dalam dunia prostitusi. Kemantapan menjadi seorang pelacur merupakan upaya untuk memaknai eksistensi diri sebagai perempuan sekaligus menunjukkan bahwa menjadi pelacur berarti menguasai 
dan menundukkan laki-laki, bukan dikuasai dan ditundukkan laki-laki seperti halnya dalam sebuah lembaga pernikahan.

\section{Simpulan}

Penelitian ini mengungkap relasi antara realitas sosial dengan karya sastra. Bagaimana pengarang sebagai bagian dari masyarakat merepresentasikan perempuan dalam karya sastra. Pelacuran yang tertuang dalam kumpulan cerpen Genduk Dukuh Seti jika diteliti dengan mengggunakan teori feminis radikal merupakan bentuk perlawanan yang digunakan perempuan untuk menunjukkan "perempuan adalah pemilik tubuh mereka sendiri”. Seksual dan pelacuran adalah cara yang digunakan mereka untuk merepresentasikan tubuhnya.

\section{Daftar Pustaka}

Fakih, M. 2001. Analisis Gender dan Transformasi Sosial. Yogyakarta: Pustaka Pelajar. Handaningrum, Rohana. 2014. “ Genduk Dukuh Seti,” Kumpulan Cerpen. Lamongan: Pagan Press.

Hellwig, Tineke. 2003. In the Shadow of Change: Woman in Indonesian Literature. California: Univeristy of California at Barkeley.

Putri, Gilang Nadia. 2017. "Seksulitas dan Kebebasan Perempuan dalam Novel Red Riding Hood Karya Sarah Blakley,” Tesis S2 Magister Susastra Fakutas Ilmu Budaya Universitas Diponegor, Semarang.

Ruthven, K.K. 1990. Feminist Literary Studies: An Introduction. Cambridge: Cambridge University Press.

Tong, Rosemarie Putnam. 1998. Feminist Thought. (diterjemahkan oleh Aquarini Priyatna Prabasworo. Yogyakarta: Jalasutra. 